\title{
Imagining Something Better: Rolas from My Border Hi-Fi
}

\begin{abstract}
The list is the origin of culture. It's part of the history of art and literature. What does culture want? To make infinity comprehensible. It also wants to create order-not always, but often. And how, as a human being, does one face infinity? How does one attempt to grasp the incomprehensible? Through lists, through catalogs, through collections in museums and through encyclopedias and dictionaries.
\end{abstract}

(Umberto Eco)

\section{1 “It Started with a Mixx"-Los Campesinos!}

When I was a teen, one of my favorite books was The Book of Lists, an almanac of curious information and trivia. The lists included "worst places to hitchhike," "people misquoted by Ronald Reagan," "18 famous brains and what they weighed," "10 words you can't pronounce correctly," etc. I had not thought about the book in years until, in 2003, I picked up Alberto Fuguet's Las películas de mi vida (The Movies of My Life), and the narrator, Beltrán Soller, starts talking about the gift he received from his grandfather: The Book of Lists. For the protagonist, that gift becomes a point of departure for the eventual listing of the 50 movies that shaped his life. Por esas cosas que pasan, The Book of Lists also shaped my life for collecting random scraps of information and for making lists. Because lists, as Umberto Eco notes, can serve as attempts to make "infinity comprehensible."

Confession: I'm a keeper of lists. Mostly, they revolve around music: the music of my life. My favorite period is that of the late '70s through mid-'90s, from roughly the birth of Joy Division through Beck, from punk through post-punk, new wave, electro and alternative. I'm a musicphile, a music geek, or, as some friends have accused me of being, a rock snob.

I think I've been this way forever. I think of my past and I recall a particular song or a band: I think of a band or song and I remember the feeling, the things that I was going through at the time. Walking around el centro histórico of Mexico City, past the traffic and crowds, I often think of Depeche Mode's Music for the Masses. I was living there when I received the album, and I used to listen to it all the time on my Walkman. The Pixies' "I've Been Tired” is another song I closely associate with Mexico City as I was also living there when the song came to me on a mixtape sent by a friend. I had a lot of mixtapes with me. Many were my own mixes, and a few came from my friends. 
Mixtapes were important for me as they maintained a link to mi gente-my family and my friends-in California.

I got into making mixtapes back in the 1980s, when I was a kid with the heart of a sad punk. In other words, high school. But I never shared those mixes with anyone. They were more my personal soundtrack culled from my collection of 45s, vinyl, and tapings off the radio. In 1984, when I entered university, I became a college radio DJ and arrived at the tail end of British post-punk-bands like the Cure, Joy Division, Gang of Four, Wire-and the rise of US indie music-R.E.M. being the key reference. This was the soundtrack of my life, and my mixtape production increased. Sometimes my tapes were culled from my own radio shows, or they were dedicated to whichever particular chica had caught my eye, or they were mixes that I made in our production studio using the vast music library of KCSC that was at my disposal. ${ }^{128}$

The best mixes construct soundtracks for a life: They are in some ways autobiographies told in three-and-a-half-minute bursts at the velocity of a cassette tape, a $\mathrm{CD}$, or an iPhone. They are stories constructed in songs that help guide the listener and reveal the narrator. They ask for a dialogue, a union, a conversation. As Nick Hornby declares, making a mixtape is "like writing a letter-there's a lot of erasing and rethinking and starting again," and making one is "like breaking up, hard to do" (88-89). Sitting in front of a computer or-if one is old-school-a stereo to listen to music, making a playlist or a mixtape can be a way of starting a dialogue or a conversation: crafting a listing of songs into a particular order is an act of identity.

At its most basic, the following is a playlist of songs that makes up so much of my life as an unrepentant border-crosser. Music adds a soundscape that can contribute to the casting into sense of a surrounding space; it can function as another way of creating a sense of place while uniting disparate places, countries, and histories. What I reflect on here, then, is a blend of the personal with the public, the autobiographical with the scholarly, to write about how music works, but more than that, what music, primarily Chicano/a and rock en español, does. How does music affect us? In particular, this is about what music did for me, one of its listeners.

\footnotetext{
128 A bunch went to a young gymnast who I thought was neat. Fortunately, she thought the same. And while that's always a good beginning for a story, this one does not end well: While my mixes were carefully planned, hers were often hastily put together. Aside from breaking many rules of making a mixtape-placing two songs by the same artist in a row, not paying attention to the flow-her mixes also told me that our musical tastes were never going to mesh. Where I offered Wire Train, For Against, and the Cocteau Twins, she responded with REO Speedwagon, Journey, and Cindy Lauper (her most "new wave" offering). Clearly, if there could be no conversation in our musical tastes, there could be no future for us.
} 


\section{2 “Everyday I Write the Book"-Elvis Costello}

After his girlfriend leaves him, Rob, the narrator of High Fidelity, sets out to reorganize his record collection. Rather than follow a common system of classification-by artist, by album, or by genre-he chooses to organize his records autobiographically. As he explains:

... I fancy something different, so I try to remember the order I bought them in: that way I hope to write my own autobiography without having to do anything like pick up a pen. I pull the records off the shelves, put them in piles all over the sitting room floor, look for Revolver, and go on from there; and when I've finished, I'm flushed with a sense of self, because this, after all, is who I am. (54-55)

By organizing his records in this way, Rob attempts to bring order to his life, which has become chaotic and messy. In the film version, this moment is illustrated by a visit from Dick, one of Rob's employees at the small record store that he owns. Dick comments on the records that are already organized and asks about the system, confessing that he can't figure it out. When Rob explains it, the expression on Dick's face is key: It is one between approval and envy. Dick perfectly understands Rob's affliction: It is the same one that all of us who place too much on a song carry. Our affliction is that of having music inside us to the point where it is an essential part of our existence. This is not about the practice of making music but about the practice of listening, of recognizing that music is a necessary, vital element.

Whenever I move to a new home, one of the first things I install is the stereo. Whenever I travel, I carry at least two pairs of headphones, in case one fails. Each gesture towards music in my life-working in a record store as a graphic artist, being a radio DJ, spending hours crafting mixtapes, wandering around cities with my headphones serving as a soundtrack to my walks-is an act of identity. When we tell someone, "Hold on, I'll make you a mix," we are offering a part of ourselves. Thanks for the Memorex, as Sarah Vowell once titled an essay of hers.

\section{3 “Mexican Radio"-Wall of Voodoo}

My life has been spent crossing borders. Up until I was sixteen years old, I spent every summer in Mexico, in Mexicali, the border city where my family is from. As an undergraduate and then graduate student, I traveled frequently to Mexico City for research. Later, my border crossings took me frequently to Spain, where I lived off and on for a number of years. In the last twelve years, my travels have taken me to Turkey. My travels to Istanbul are so frequent that it is thought that I really live there and occasionally fly to New Mexico to teach. 
In my wanderings, as my friends on Facebook know, I frequently reflect on travel and migration, on forms of border crossing, on my passages through the Middle World that exists in the seams between countries and communities. Border crossing, migration, wandering-touching intervening spaces-opens up the possibilities of "alter/native ficto-historical texts that can create a world in process while continually freeing themselves from their own biases" (Gaspar de Alba 12).

My work in general flows along these hybrid cultural strategies, which I have termed Wandering strategies, and what Chicano critic José David Saldivar identifies as pensamiento fronterizo or border thinking-a process that comes from the marginalized to undermine hegemony. Wandering resists domination and exploitation through a high degree of hybridity. By focusing on wandering, notions of a point of departure, or of arrival, become less important: What matters is the journey. ${ }^{129}$

It needs to be stressed that Wandering does not imply a mindless meandering, not a wandering lost, but a journeying along multiple trajectories, guided by the itinerant system of signs that the borderlands offer. Wandering culture wanders-flowsin the limen between cultures to construct not a fixed place but rather to deterritorialize the notion of fixed cultural identities. The identity that arises is not one based on territory; rather, the border identity that is proclaimed is forged between national cultures, in a migrant movement that is situated in an intervening space.

\section{4 "Desaparecido"-Manu Chao}

A day after arriving to Paris at the end of May in 1998, I stopped into the Virgin Megastore on the Champs Élysées to see what I could find. It was there that I found out that Manu Chao, lead singer of Mano Negra, had recently released his first solo album, Clandestino. Having been a fan of Mano Negra and the way in which, over the course of four albums, they traced a musical geography that incorporated punk rock, American jazz, Moroccan rhythms, reggae, dub, punk, and United States/Mexico border music into one highly diverse package bordering on caótico, I bought the CD without going to the listening station. Clandestino is a musical bomb thrown at the heart of rock/world/ethnic music, enacting a form of globalization not from above but from below, from the streets. In a continuation and departure from the final Mano Negra album, Casa Babylon, Manu has pared down the multiple layers to basic beats, but no less eclectic than what he had done in the past. Under a multi-textured soundscape incorporating sounds from the so-called Third World-North African leading to Carib-

129 This is different from the notion of travel. As Iain Chambers states, "to travel implies movement between fixed positions, a site of departure, a point of arrival, the knowledge of an itinerary. It also intimates an eventual return, a potential homecoming” (5). 
bean to Latin American-Manu sings of wandering, of conflict, of crossing borders, of migrants forced to travel diverse routes in search of work.

In many ways, Manu sings from what Breyten Breytenbach has called the Middle World, a space between the First and the Third Worlds where the main condition its citizens-uncitizens, he calls them-know is migration. For Breytenbach, the Middle World uncitizen is one who has ventured into zones where "truths no longer fitted snugly and where certainties did not overlap, and most likely they got lost there" (135). Breytenbach's model for the Middle World is helpful for understanding the consequences of mass movements across borders. He further emphasizes that though the Middle World is everywhere, "belonging and not belonging," it is not "of the Center ... since it is by definition and vocation peripheral; it is other, living in the margins, the live edges" (136). ${ }^{130}$ It is a border space connecting all other border places, in an archipelago of wandering.

This soundscape that Manu lays down is a blending not just of different styles, but also national terrains, primarily from the global South. In this fusion, his songs construct an audiotopia of the Middle World. An audiotopia, as Josh Kun remarks, is a sonic space "of effective utopian longings where several sites normally deemed incompatible are brought together" (23). As a site, like Foucault's concept of heterotopia, it contains multiple sites/histories/narratives. The music of Manu Chao offers an audiotopic map of geographic encounters, a wandering across borders and time zones into a contact zone that lies between nations.

Crossing a border is always a crossing, if only briefly, into the Middle World. But sometimes, in the case of migrants who are forced to leave their countries-because of exile, because of economic conditions-the passage through the Middle World can be longer as they adjust to the new social realities. In some cases-as Manu sings in "Desaparecido"-there is no adjustment, no acculturation, and no nostalgia for the home left behind but rather a permanent state of suspension.

1998. Summer. I am on an overnight train from Paris to San Sebastian, in the Basque country. As the nocturnal landscape passes with the rumble of the train, I sink off into sleep, the songs of Clandestino in my ear, the CD player on repeat. From San Sebastian I travel to Bilbao, to Barcelona, to Madrid, and back to Paris. Throughout the train trips Manu is constantly singing. Overnight to distant cities in Spain and France, I am traveling also to Jamaica, to Cuba, to Algeria, to Chiapas. I am traveling also to Tijuana, the central city in this geography that Manu is mapping. Listening to

130 For him, to be of the Middle World "is to have broken away from the parochial, to have left 'home' for good (or for worse) whilst carrying all of it with you, and to have arrived on foreign shores (at the onset you thought of it as 'destination', but not for long), feeling at ease there without ever being 'at home'” (143). Breytenbach also speaks to various levels of Middle-Worldness: from the trauma of exile to the economies of migration to the tragedy of being a refugee to the possibilities of being an expatriate. The Middle World posits a counter-narrative to the flows of power that would attempt to control, to place limits. 
the music while crossing Spain, I move to the beat of the Middle World, placed and misplaced-a young border crossing Chicano straddling the north and the south at the same time-in different locales and temporalities. With this album, Manu shows that more than a musician, he is a border brujo, crossing-and in the process crossing out-borders to create new geographies.

\section{5 “One Step Beyond"-Madness}

October, 1984. About a week after entering university, at the end of August, 1984, on a whim I walked over to the student-run campus radio station, KCSC. As a shy teen who often felt misplaced in social situations, I spent most of my weekends in my room at home, listening to music. The last few years had been difficult. One of my younger sisters, the one closest to me in age, had contracted cancer at eleven; This was less than a year after my parents had divorced. The upheaval of the divorce and then my sister's cancer shook our lives with the force of an earthquake. With the mounting hospital bills and my sister in the cancer ward at Stanford, my mother couldn't afford to keep all her children together. My youngest sister went to live with my grandmother, my brother and my other sister went to my father. Since mom found it difficult to find a place for me, I lived with her for six months until she could convince one of my aunts in San Diego to take me in. In the meantime, I spent my weekends next to my sister in the cancer ward. I slept on a cot by her side. After a year, mom was able to reunite her children under one roof in San Diego. A year later, my sister's cancer in remission, mom moved us all back to northern California, to the small farming town of Orland, where I had lived until the divorce.

We lived in a farmhouse on the edge of town, and on Saturday nights, I would be in my room, reading and listening to the radio. A nerd, a geek, with few social skills. One night, while moving the dial, I picked up the strains of a song that I hadn't heard since moving away from San Diego, “One Step Beyond,” by Madness. My siblings and I were sitting in the living room one night watching a TV station that occasionally showed music videos when this crazy song came on with six guys bouncing around to a rock-steady beat. My sister and I were hooked. Finding that song on the radio in northern California was a revelation. Since returning to that part of the state, the new wave and punk that I had been listening to in southern California had been replaced by classic rock that said very little to me. The radio program was from a tiny station in the Sierra Nevada mountains that had blocks of programming. One block would be folk music, another would be reggae, another would jazz. On Saturday night, three hours were dedicated to punk and new wave. It became my favorite radio program, though I couldn't always tune in. The station was far from Orland, and the reception was never that great. But when I could get it, I would hear the music that shaped my 
life from then on. It was there that I first heard New Order, Joy Division, the Stranglers, and the Cure. It was there that I began to consider the possibility of working in radio.

On my first visit to KCSC, I was unsure of the process. Walking into the station, I was taken by the used furniture, the walls covered by posters for bands, the air of an operation working on a shoestring budget. While standing there in the lobby, taking it all in, a woman came out of one of the offices. She asked me if there was something I needed help with, and I stammered out, "I want to be a DJ."

At the beginning of October, at 1:45 in the morning, I rode my bike over to the station where I was greeted by the DJ who had the Saturday night 10 p.m. to 2 a.m. slot. As he prepared to end his show and I got ready to start my first, he asked me: "Do you have a radio name?” I hadn't thought about one, but finally I said: "Jimi, Jimi the Geek."

At 2 a.m., on that early October night in 1984, I opened my first radio show with “One Step Beyond." For a person with a low sense of self, one who had trouble speaking in public or in social situations, working on the radio was transformative for me. I found my voice on the radio, and found a community of other misfits like me; people who moved to a different beat, who created art, who lived and thought and loved in ways that were distinct from the mainstream.

\section{6 "Con la tinta de mi sangre"-Los Relámpagos del Norte}

In his novel Out of Their Minds: The Incredible and (Sometimes) Sad Story of Ramón and Cornelio, the Tijuanense writer Luis Humberto Crosthwaite adds to the musicality of his border city of Tijuana through a novel about two friends from there who go on to become one of the most popular norteño duos in Mexico. The novel is a fictional, and parodic, biography of two norteño superstars, Ramón Ayala and Cornelio Reyna, and their rise to fame as the duo Los Relámpagos del Norte. In the novel, the two friends are simply Ramón and Cornelio and their band is Los Relámpagos de Agosto. ${ }^{131}$ One of the characters in the novel is their manager, my literary counterpart, Jimmy Vaquera, a Chicano from California who feels, literally, that he carries music inside him.

In the chapter "Heaven, I'm in Heaven," Jimmy recounts to Ramón y Cornelio his relationship to music. ${ }^{132}$ He claims that he carries music, literally, in his veins.

131 The name of the band is both a reference to the band of the real Ramón $y$ Cornelio, but also a reference to a novel by the Mexican writer (and brilliant ironist) Jorge Ibargüengoitia.

132 Though the novel was originally written in Spanish, I am quoting from the English translation. Where in the original, many of the chapter titles take their names from classic norteño songs, the translator, Johnny Bird, has replaced them with titles of songs from the US songbook. 
And because of this, he has a close connection to it. He explains how at the age of four he tripped and cut his knee: "It was terrible and beautiful. Blood was spurting, it wouldn't stop flowing, coloring the floor, and together with the blood, music came sailing, grandiose, emanating from my veins. Of course, no one else could hear it ... because it was inside my body" (46). He goes on tell them how in high school he tried to show a girl he liked what flowed through his veins. He wanted to share his music with her and so he slit his wrist. ${ }^{133}$ Jimmy ends up in the hospital where he is given a blood transfusion that frightens him. To him this is the worst thing that could happen. He asks himself: "What if it was the blood of someone that was tone deaf? What happened if this transfusion was the end of my melodious circulation?" (46). When he has the chance, he opens the wound and is pleased to discover that "my blood, my heart, my veins and arteries continued to be my own orchestra, my own private soundtrack" (47).

Music for Jimmy, as it is for Rob in High Fidelity, is his own form of rootedness. While it lives inside him, it keeps him grounded, and he realizes that he must protect it. And being a Chicano who understands what it means to be displaced-crossed by the border, placed and displaced by both Mexico and the United States-he knows that grounding in a region like the northwestern Mexican borderlands, a space that is often defined by its migratory flows, has to be found in forms other than roots in land.

\section{7 "Noche oscura"-Café Tacvba}

1993. The first time I heard about the Café Tacvba was in a fanzine I picked up in Mexico City in 1990. I was intrigued in this new Mexican rock band who performed in a variety of regional genres-boleros, jarochos, norteño-along with fast punk style songs using primarily acoustic instruments. On subsequent visits to Mexico City, I would spend my Saturday mornings at the Tianguis del Chopo, a vast Saturday market dedicated to music, from rock to blues to punk to electronic to reggae. There were T-shirts, bootleg tapes and CDs, and vinyl records, and the place was crowded with rockers, punks, and other members of the diverse Mexico City subcultures. On one visit, I left with a pile of tapes of strange electronic and folk music; on another, I walked out with bootleg tapes of Caifanes and Café Tacvba. So, in the spring of 1993, when I heard that Café Tacvba were playing at the famed Whiskey A Go-Go in Hollywood, I knew I had to go.

133 This act is an intertextual reference to the classic song "Sombras" by José María Contursi. The song begins with the singer declaring that he would like to open his veins and spill his blood at the feet of his lover, to show her the limits of his love for her. Though originally composed as a tango in 1943, the song was recorded in 1964 by the Mexican Javier Solís as a bolero ranchero-a type of arrangement in the ranchero genre that fuses Mexican mariachi instrumentation with a bolero beat. 
When the band bounded out onto the stage, Meme leapt to the keyboard and melodica at the back, Quique ran out with a wooden upright bass, Joselo with his acoustic guitar, and then came the lead singer, Rubén Albarrán, in a Mexican fieldworker outfit and a straw hat. ${ }^{134}$ The band appeared to embody the folkloric imaginary of the Mexican held by the United States, the fantasia represented by Speedy Gonzalez and other racist stereotypes used by United States popular culture to imagine Mexico as backwards and poor. Launching into the opening track of their self-titled debut, "Noche oscura," the Tacvbos demonstrated their musical skills as the singer bounced around the stage like Speedy Gonzalez gone punk. In embodying the United States hallucination of the Mexican, the band subverted that imaginary by laying claim to it. In their musical genre mixing, from ranchera, to bolero, to cumbia, to punk, they cultivated their own Mexican and rock imaginary through a bifocal perspective, creating families of resemblance to not only Mexican regional music, but also to a rock tradition, one that flowed not from North to South, but rather, South to North.

\section{8 “Ay te dejo en San Antonio"-Los Lobos}

In the introduction to his edited collection, The Tide Was Always High, Josh Kun notes how Blondie's inclusion of mariachi horns in their cover of "The Tide Is High" is an example of how Latin America, or more precisely Latin America in Los Angeles, inserts itself into North American punk. The particular audiotopic fusion of the song, a reggae song from the Caribbean covered by a New York punk/new wave band and recorded in Los Angeles, slyly creates a musical geography where the Americas come together. What is fascinating about Kun's telling about the recording of this song is his focus on the uncredited session musicians who contributed to it. With an ethnographic eye towards examining the conditions of the recording process, he is, in some ways, exposing the scaffolding that holds the process together, the musicians who make their living recording for others. By telling their stories, Kun illustrates how session musicians, primarily from Latin America, hold up the California sound of the late '70s and early '80s, in music by Linda Ronstadt (prior to Canciones de mi padre) and Jackson Browne.

In his book, Dangerous Crossroads, George Lipsitz reminds us that due to popular music's relationship to place, it "alters our understanding of the local and the immediate, making it possible for us to experience close contact with cultures from far away" (3). We can note this in the Blondie version of the "The Tide Is High" in its mapping of an audiotopic space that blends two particular musical histories, the incorporation of reggae and other Caribbean rhythms by British punk, primar-

134 The lead singer, Rubén Albarrán, often changes his name for each album. 
ily the Clash, and the recognition of Latin American musical traditions within L.A. sound. The fusing of Caribbean reggae in songs like "Rudie Can't Fail," and "Guns of Brixton" by the Clash, and in the British Two-Tone movement bands like the Specials, Selecter, and Madness, is a recognition of migration into the UK. On the West Coast of the United States, this migration is primarily Latin American, and the incorporation of mariachi, or other Latin rhythms, is noted in bands like Los Lobos or el Chicano.

While most would remember Los Lobos' version of “La Bamba," it is with their first nationally distributed record ... And a Time to Dance where we can see how they-like Manu Chao fifteen years later-musically cross borders. ${ }^{135}$ Though not as outwardly experimental with sound as Manu Chao-or Mano Negra-on this album, Los Lobos are masters of playing a diversity of genres, from Mexican boleros to Cajun $z y d e c o$, to Tex-Mex and straight-up rock-and-roll and blues. Coming out of the L.A. punk scene, Los Lobos are not a band that one would associate with punk rock. However, as Alicia Armendariz Velasquez-a.k.a. Alice Bag, the lead singer of the hardcore punk band The Bags-notes in her autobiography Violence Girl, "There was no clearly defined punk sound, no dress code ... the movement was one of individuals and individual expression" (222).

... And a Time to Dance is composed of seven songs, three of them cover versions, including the Tex-Mex classic "Ay te dejo en San Antonio.” The song, originally written by Santiago Jiménez Sr., and popularized by his son Flaco Jiménez, is a classic, fast-moving Tex-Mex polka where the accordion takes the lead. That it would enter into the repertoire of an east L.A. Chicano rock band is obvious; that it became popular with punk rock crowds in the early 1980s is less so. However, if we recall Alice Bag's quote about there not being a clearly defined punk sound, it makes sense. There is a family of resemblance, not just in Los Lobos' own love for covering songs from the Mexican American community, but also in the idea of punk rock as being music played fast and out of control.

Songs are not only a set of signifying practices that create an affective bond in the listener. They are also diatopic and diachronic-they contain multiple places and times-at the same time that they are syntopic and synchronic-they are the product of one place and time. "Ay te dejo en San Antonio" will always be a song from south Texas, but each time it is performed by a different band, or heard by a listener, it is recontextualized for that time and that place. Cover songs are very interesting in this regard, for they bring with them the traces of the original, but at times are often new renditions for a different moment in time. They are, at their base, translations that are both faithful and unfaithful to their original while creating a dialogue with it. Though the Los Lobos cover of "Ay te dejo en San Antonio" hews closely to the original, their

135 The album ... And A Time to Dance came out on L.A. punk label Slash in 1983, but in 1978 the band self-released Del Este de Los Angeles, an album of covers of traditional Latin American regional folk songs. 
cover of Richie Valens's “La Bamba” demonstrates their own role as musicians, but also as musical anthropologists, as I will discuss below.

\section{9 “Aklım Nerede"-Biz}

November, 2007. A few minutes after checking out of my hotel in Ankara, I got into a taxi to head to the train station to catch a train back to Istanbul. Three minutes later, and about two blocks from the hotel, the taxi stopped dead in the middle of the street. It was November 10, 9:05 a.m. At that time, on that date every year, everything stops. Everything. For one minute, sirens all over the country sound in commemoration of the passing of Atatürk in 1938. I sat in the back seat of the taxi and noticed that a couple who had been walking down the street were also stopped in their tracks. The taxi driver turned off the stereo. We sat in silence listening to the sirens. I imagined that even the birds stopped.

And after the sirens cut off, the couple began to walk down the street, and the taxi driver turned on the stereo and started the car. The driver then began to ask me questions. He had almost no English, and I could make out some words here and there, though my Turkish was extremely limited. Most of our conversation consisted of hand signals-mostly thumbs up-and nodding. At one point, we began to talk about music. I think. The driver put on a CD of Turkish Arabesque music, and we talked about that, too. I think. The driver liked the music. I did too, as I recognized in the singing themes of longing and melancholy. When I first heard Arabesque, it immediately reminded me of Mexican ranchera music, primarily boleros rancheros, as I associated the music with working-class listening tastes. I asked who was singing, but couldn't figure out the response from the driver. When we got to the station to catch my morning train back to Istanbul, the driver popped the CD out of the stereo and handed it to me. A gift.

On the train back to Haydarpaşa station in Istanbul, I listened to a mix of Arabesque and Turkish pop that I had on my iPod and thumbed through my ragged copy of Daniel Kalder's book on anti-tourism, Lost Cosmonaut, where he chronicles his travels to the forgotten regions of Russia. Nearing Istanbul, I switched my playlist over to a mix of the Pixies, the Breeders, and Throwing Muses, bands from the late ' 80 s and early ' 90 s who shaped a large part of the music of my life. As we entered the city limits, the Pixies’ song “Where Is My Mind?” came on, and it seemed a fitting song for arrival in a city that still confused me in many ways.

2017. A decade later, while I am living in Ankara, a friend recommends that I check out a Turkish band, Biz. They do a cover of "Where is My Mind?” in Turkish, "Aklım Nerede." As the familiar instrumentation comes on, giving way to the singing in Turkish, I remember the Turkish taxi driver and our halting conversation about music on the way to the train station. 


\section{0 “We Don't Need the English"-The Bags}

In Penelope Spheeris's film, The Decline of Western Civilization, a documentary on the late 1970s punk rock scene in Los Angeles, Alice Bag, in a tight pink mini-dress and pink pumps-looking for all the world like an angry chola-struts intensely across the stage, staring out at the audience while excoriating a society based on "gluttony."

In her memoir, Violence Girl, Alice Bag writes about her struggles to come to terms with her Mexican American identity in Los Angeles in the early 1970s. A fan of progressive and glam rock, she had difficulty identifying with the Chicanas at her high school. Her sense of alienation from the Chicano community and her father's Mexican community was profound, and her way out was through music, primarily the punk rock scene in Los Angeles that was coming into importance and giving voice to a generation of disaffected youth growing up in the urban center. She writes, "When punk came along, it was just the perfect vehicle to express who I was as an individual. It was completely new and wide open" (222).

The punk aesthetic, coming out of Britain in the mid-'70s, appealed to the Chicano and Chicana urban youth for its DIY (Do It Yourself) ethos and its critique of the status quo, of poverty, of sexuality, and of class inequality. In the case of the Chicana punk rockers like Alice Bag or Teresa Covarrubias (lead singer for The Brat), Michelle Habell-Pallán astutely notes that the "visual and sonic language of the punk subculture allowed them to express their private rage about restrictions placed on and the violence done to their own bodies and to their mother's bodies" (156).

Chicano punk from Los Angeles, while at times stylistically similar to the British version, also drew upon local, regional styles to create a connection to the Latino/a musical history of Los Angeles. When the Bags sing, "We Don't Need the English," Alice Bag is referring not only to British styles of punk, but also British and US styles of sound or dress. We can see this in the way that Alice Bag presents herself in The Decline of Western Civilization, strutting across the stage in a pink mini-dress, removed from what we often associate with "punk culture": jeans, ripped t-shirts, bondage wear, and safety pins.

In these moves to distinguish British punk from Chicano punk, we see how bands like the Plugz, the Brat, Los Illegalz, and the Zeros demonstrate that punk is not about musical conformity, but about refusal. Punk is refusal. Refusal of social norms, of style, of constraints that would attempt to define a community. Thought of this way, we can see how punk can be a vital survival strategy for my generation of Chicanas and Chicanos, Mexican Americans who find themselves marginalized and disenfranchised by various society gatekeepers. The embrace of punk is not a denial of culture or heritage, but a rethinking of how we as Latinos can relate to culture and heritage.

The Chicano generation gave us post-Chicanos a voice and offered a path for getting out of cultural marginalization. That path was to stand and declare our own right to be first-class citizens of these United States. The question that they posed, as a generation, could be asked in this way: "Who are we?" An important and necessary 
question that every cultural, regional, national identity needs to ask itself. "Who are we?” the Chicano poet Ricardo Sánchez asked, later responding: "We are the urgent voices" (131). Our voices need to be heard.

\section{1 “Latinoámerica”-Calle 13}

September, 2016. 90 minutes into welcoming 50, I strolled back to my place with my earphones in place. I pressed play, to see what song my iPhone would give me. "Latinoamérica” by Calle 13. With that song as an opening soundtrack for the next year of my life, I walked beneath the trees that line my street. Just before turning into my apartment block, I stopped beneath a street lamp and looked out around me, at the sleeping buildings, the closed shops, the occasional passing cars, and the towers of the city in the distance. And I thought too of the routes that had led me to Turkey. I thought of my connections to home-wherever that is-and to my family and my friends, spread out over multiple continents, countries, and time zones. I thought about the stories that bring us together, that connect us, that bind us as a community.

Standing beneath that streetlamp at 1:30 in the morning, on my quiet street on the edge of Ankara, I thought about all this, about routes and roots, about the personal soundtracks we make in our steps, about the secret pathways of the heart and the power of communion and community.

\section{2 “Don’t Push Me Around"-The Zeros}

In Jim Mendiola's short film, Pretty Vacant, we see this question of how to merge Latino ethnic identity with punk culture-short answer, you don't question your ethnic identity, but you embrace the diverse possibilities of cultural identity. Near the beginning of the film, his protagonist, Molly, speaks to this directly when she mentions that she was born on the day that the Raza Unida party met for their first national convention, and which was also the day that David Bowie released "Ziggy Stardust." In making this claim, she is inserting herself into the intersection of ground-level Chicano activism and global pop culture and promotes a bicultural, bifocal identity.

The film is shot in black and white and told in voice-over, giving it a very DIY punk aesthetic that resonates with the Chicano/a cultural practice of rasquache. Rasquache, as the Chicano critic Tomás Ybarra-Frausto describes it, is an aesthetic practice of Mexican origin that is defined by resourcefulness, irony, and the transformation of quotidian articles into aesthetic objects. As he writes, "Bright colors are preferred to somber, high intensity to low, the shimmering and sparkling over the muted and subdued" (5). In a sense, it is a practice by a marginalized class to make do with material objects at hand. In the case of the creation of art, rasquachismo is 
an oppositional praxis of resistance to a dominant aesthetic code that "both evades power and empowers itself” (Gáspar de Alba 12).

As an example of rasquache or DIY film-making, Pretty Vacant is very self-aware of its aesthetic. There is a cut-and-paste feel to the movie, as if it were constructed out of many different fragments, almost like a punk zine from the 1980s. This is made even more evident by the fact that Molly is a bisexual, working-class Chicana punk who makes art out of found objects and also has a zine, Ex-Voto. While the zine is San Antonio-based, it also has readers in California. This highlights the sense of a punk, alter-Latino community at a distance, one that is bound together through alternative material culture, zines, comic books, and music. The film tracks a week in the life of Molly as she puts together the latest issue of Ex-Voto, prepares for a show with her band, and avoids her father. The main story of her zine is about how she discovered a clue that the Sex Pistols were going to merge punk with Tex-Mex, but they broke up before this could be realized. Her band is called Aztlán a Go-Go and is a trio of women. She is avoiding her father because he is preparing for the annual family vacation to Mexico, and she wants to stay behind to work on her art.

There is a scene that illustrates well Molly's bicultural identity. In it, there is Molly in profile cutting out images for an altar that she is building while she talks about her family's annual trip to Mexico. It is largely because of her father, who, though he was also born in San Antonio, feels that it is an important tradition to keep. She can understand his desire for his annual reconnection to Mexico, but she does not feel it necessary for her. On the wall to her side, she has posters of Che and Zapata. As she says-in voice-over-that she has "other concerns," the camera switches from a profile shot to a close-up shot of Molly and the wall behind her. On it is a vast cut-andpaste collage of punk bands-the Ramones, the Clash, the Sex Pistols-and Chicano popular culture, primarily comics-the work of the Brothers Hernández and their classic 1980s comic, Love and Rockets. What we see with this scene is the merging of Molly's interests: punk rock, Chicano/a culture, and Latin American political history. The collage demonstrates one of the film's central themes, the mixing, blending, and fusion of different objects of culture. Molly's room in this brief scene also spotlights how Chicano and Chicana artists and punk bands of the 1980s and 1990s transformed punk culture into sites of possibility where national and transnational conversations could take place.

\section{3 "The Headphonist"-Kinky}

October, 2016. Whenever I visit a city I make it a point to hit up record stores. On a visit to Istanbul, I spent a few hours one night with a record store worker pulling out and listening to CDs of various types of Turkish music, from the Turkish pop of Gülşen through the Arabesque of Ibrahim Tatlises, the Kurdish songs of Aynur, the ambient 
sounds of Mercan Dede, to Sufi music. On my first visit there, in an out-of-the-way record store crammed into a space about the size of a utility closet, I picked up a couple of CDs of Turkish pop and one mixtape CD of Turkish pop hits. In Mexico City, upon entering Gandhi bookstore, I would often head first to the music section to flip through the racks.

In Dublin, in the fall of 2016, while walking around with my headphones on, I ended up at Tower Records. I had not been in one since the 1990s when I used to go to a Tower Records in Mexico City. Though I do not buy as much physical music as I used to, I still had to step inside as Tower Records holds a special place in my memories. In the 1980s, while a college radio DJ in Chico, California, I worked for a time at the local Tower. In Dublin, I spent an hour wandering through the stacks, flipping through the vinyl, recalling the years spent in record stores, the albums that shaped my life, and the songs that make the soundtrack of my life. Whereas in the past I would often leave a record store with a pile of CDs or vinyl records, on that trip I walked out with a couple of stickers, but a lot of memories.

\section{4 “Tijuana Sound Machine"-Nortec Collective}

There is this: The border is sound. It is in the sounds of the cars waiting to cross; in the crowds; in the mix of sounds from the mega dance clubs and the honky-tonks steps away from each other in the border cities. Cruising Revolution Avenue in Tijuana on a Saturday is a trip across a varied aural landscape. The urban sounds connect distinct places. By disrupting notions of national homogeneity (if such a thing ever existed), the mixed sounds and languages coming from the mega-discos, nightclubs, and the stereos of passing cars negate the physical, material border instituted by nations trying to impose border controls.

Like other bands from northern Mexico-such as Plastilina Mosh, Kinky, and El Gran Silencio-and the United States Southwest-in particular, Piñata Protest-the Nortec Collective use the sounds of the border, constructing musical geographies to unite disparate places: mapping out the soundtrack of the Middle World. Through the use of tape loops of northern Mexican banda mixed with European techno, the collective constructs a soundtrack for another type of migrant passing through the Middle World: the migrant who follows the global flows of electronic music. But it also illustrates how the border is made up of migrant flows, of diaspora, of transculturation. The loops of norteño music threaded through the electronic background are traces, echoes, specters of a larger history of migration and flow in the borderlands. El Gran Silencio, from Monterrey, Mexico, and Piñata Protest, from San Antonio, Texas, construct a hybrid sound built upon a norteño grouping: an accordion, acoustic and electric guitars, drums, and keyboards. But instead of playing "traditional" northern Mexican music, their sound slips and slides between cumbia, norteño, punk, and ska. 
As with the music of Café Tacvba, when these bands unite Latin American rhythms with US rock, they lay bare the connections across borders, and align themselves with histories of migration, both northern and southern. What bands like these do is not just cut up musical DNA but scramble and reconfigure it to show off the borderland's audiotopia.

\section{5 "El extranjero"-Enrique Bunbury}

May, 2017. After a long day at the office, I take the faculty service bus back to my neighborhood in Ankara. Though I always greet my fellow passengers on the bus, I often sit alone, wearing my headphones. It's not because I don't like them; it's because in the nine months of living in Turkey, my Turkish hasn't advanced much.

In Turkish, the word for foreigner is yabancl. It's a word that I closely identify with, not just because I'm a foreigner in Turkey, but because my life has always been, in a way, about being foreign. Wherever I go, I've always been an extranjero, a yabancl, a foreigner. A few months earlier, on the metro to downtown Ankara, a man approached me to ask a question. I pulled off my headphones and asked him to repeat his question. I think he was asking me for directions somewhere. This was something that often happened to me in Turkey; I was often stopped because it was believed I was Turkish. When I told the man that I didn't speak Turkish, he stared at me as if he didn't believe me. On a flight once to Istanbul from Munich, a man sitting beside me was convinced that I was Turkish. When I told him I wasn't, he thought I was trying to deny my heritage, that maybe I was a German Turk, an Alamancl, ashamed of my background because I couldn't speak. As soon as I spoke, the man on the metro looked at me for a bit before stepping back and telling everyone in our vicinity, "Yabanc1." "Evet, ben yabanc1," I responded. Yes, I am a foreigner.

Sometimes, when people ask me where I'm from, I tell them Mexico. It is easier for me as then I don't have to go into an explanation of what it means to be Chicano. If I could speak more, I would probably say that I'm a permanent yabancl, that I feel out of place in English and Spanish. When I was in graduate school, at the University of California, Santa Barbara, I once went to a public lecture by Derrida. One of the first things he said was something along the lines of "the language that I am speaking to you is not my language. But it is my language."

The tongue in which I write is not my own, but it is.

\section{6 “La Bamba Rebelde"-Las Cafeteras}

As Chicanos born in the 1960s, my generation-Generación meX-sought out a voice that departed from the Chicano movement while at the same time furthering its aims. 
For communities living between cultures, hybrid strategies for negotiating the limen between national cultures or centers of power become empowering methods of constructing identity. This blended identity-meshed in language and cultural attitudecan best be described through a term used by Alicia Gáspar de Alba: Alter/Native. Our generation forges an alternative path-in style, in attitude (ours is a generation that loves both Oldies music and the Smiths)-but also an Alter/Native identity to the earlier Chicano movement generation and to United States culture in general. Through Alter/Nativity, we imagine something better, something that fits our particular style. The generation that follows mine, Gen Latinx, needs to continue to do this, especially as we suffer through yet another cycle of violence against our communities.

One strategy is through recovery or refashioning of models from popular culture. An example from music would be "La Bamba." The Richie Valens version is enlightening, for it comes at a moment when there is a sort of Latin boom happening in the United States I Love Lucy was one of the most important TV shows at the time, Latin dances like the cha-cha-cha and the mambo were the rage, and then along comes a young Mexican American with a rockified rendition of a traditional son jarocho, "La Bamba." This song, borrowed from Mexican folk tradition-a son jarocho from the state of Veracruz-incorporated into a 1950s rock grammar, becomes one of the biggest hits in rock-and-roll, and its influence continues to be felt today. ${ }^{136}$

Ralph Ellison once said that the US is "jazz shaped.” It might be argued that rock music in the Southwest is "La Bamba" shaped. For each historical moment in which the song is covered, in the late 1970s with the punk version by the Plugz, the 1980s with the Los Lobos version, and recently with the version by Las Cafeteras, it has been restructured to include not only its particular moment, but also to refer to an earlier one. While the Los Lobos 1987 rendition is the most recognized, the version that might have the closest family resemblance to the Valens version might be the 1979 punk version by the Plugz. Though speeded up for a punk rock crowd, the raw recording and instrumentation is fairly close to the Valens version, and the major differencesaside from the speed, the Plugz version clocks in at one-and-a-half minutes while the Valens version is thirty seconds longer-are in the lyrics. The Plugz add a verse where they claim to be against capitalism and supporters of anarchy.

The Los Lobos "La Bamba" also sticks close to the instrumentation of the Valens version, at least at the beginning. But, following the guitar solo, a zydeco accordiona throwback to some of their earliest songs, like "Let's Say Goodnight"-is added to the mix. And, at the conclusion, the song harkens back to its more traditional/folk version with the rock song blending effortlessly into the son jarocho. In this way, Los

136 "La Bamba" has its roots in Veracruz. Its earliest recording is in 1939, and the Valens rock-androll version is from 1958. It becomes an immediate top 40 hit on the US charts and even charts around the world. Though not acknowledged, the Beatles hit, "Twist and Shout," from 1963, bears a strong resemblance to the beginning of "La Bamba." 
Lobos not only insert "La Bamba" into a longer history of American music-with the zydeco accordion-but also tie it back into its folk roots. In so doing, they lay bare its trans-American roots.

Las Cafeteras-also from L.A., like the Plugz and Los Lobos-bring La Bamba back to its roots by playing it in a more traditional jarocho style. If the late 1970s and early 1980s Chicano rock scene was informed by punk-in bands like the Zeros, the Bags, or the Plugz-in the 1990s, it was rock en español-Ozomatli being a key referenceand since the beginning of the twenty-first century, the scene has gone back to more folk roots with bands like La Santa Cecilia, Cambalache, and Las Cafeteras. One of the scenes is built around jarocho and the concept of convivencia. As Martha Gonzalez uses it, this term-which literally means "coexistence"-is the "act of being with each other as community" and is a "social, moral, and musical aesthetic" (270). ${ }^{137}$ In building a sense of convivencia around the praxis of jarocho, the organizers of the scene strive for communal relationships over musical "product." One of the bands that formed around this scene was Las Cafeteras, a group of men and women who use the son jarocho as a tool for social activism and awareness. Their rendition of "La Bamba," which they call "La Bamba Rebelde," embodies this.

The folk version of "La Bamba" is performed by a group playing traditional instruments from the region, including the jarana-a type of small, eight-string guitarand the harp. When sung, "La Bamba" has multiple verses, far more than the Valens version, and each singer of the band takes a verse. At the end, the final singer calls for the song to conclude. The rock versions of "La Bamba" do not do this.

Las Cafeteras, however, not only bring back the folk instrumentation, but also the multiple verses. Each verse is dedicated to a different social topic within the Chicana/o community. In one, the singer calls out that they, the band, are Chicanos from east L.A. In another, the singer calls out to the Dreamers, another to Chicana feminism, another to the need to cross borders. The bands brings to the fore the rebel possibilities of "La Bamba," hence the rebelde in the title of their rendition. What "La Bamba Rebelde" does is create community and cohesion through a song that has crossed multiple borders.

In these renditions of "La Bamba," we can hear how music is grounded in one specific place and time-syntopic and synchronic-but at the same time, it is also diatopic and diachronic in the sense that diverse spaces and diverse times converge within it. The audiotopias are transnational and speak to migration and border crossing.

137 Convivencia is also a term used by scholars of Spanish medieval history to talk about the period from the eighth century to 1492 when the Iberian peninsula was conquered by the Umayyad Caliphate-in 711-and reconquered by the Spanish Catholic kings in 1492. In the centuries before the completion of the Reconquista, it is hypothesized that the three major religions on the peninsula, Islam, Judaism, and Christianity, coexisted in relative peace. 


\section{7 "La vida es llena de cables"-Señor Coconut and His Orchestra}

May, 2005. There we were, three Palestinians, a Canadian-Lebanese, a young Turkish student, and me, sitting in a bar in Izmir, Turkey. MTV was on the television, but we were concentrated on our conversation. Though we had all come from different countries-one of the Palestinians was completing his doctorate at the Amsterdam School for Cultural Analysis, another was a professor in London, the third taught at a university in Gaza, the Canadian-Lebanese was a grad student in the process of reconnecting with her Arab roots, and the undergrad from Izmir, the only local, was our translator and guide-we had all come together as a group united by our own excentric experiences.

We were in Izmir for the Cultural Studies Symposium at the University of the Aegean, Ege Universitezi. The theme of the symposium was "When 'Away' Becomes 'Home:' The Cultural Consequences of Migration.” Sitting around that table, we all lived the consequences of migration.

Later, all of us piled into a tiny taxi driven by a Kurdish man, and we all began to sing Arabesque music, though half of us-in particular, me-didn't know or understand the lyrics. That taxi, full of nationalities and cultural identities, took us through the streets of the ancient Smyrna, now Izmir, to a basement bar near the university. At the same time, stuffed into a Kurdish taxi, we were on a nocturnal paseo through the Middle World, guided by a soundtrack of Arabesque music.

The music that we hear, the music that we carry deep inside us, is more than simple background music. The music that we hear is the music that transforms us and marks out a zone of resistance, a spot through which we can open up a space for critique, for seeking change, or for gaining agency. It is a series of cables that connect us to others and to other places, like in the musical geographies of Manu Chao, Los Lobos, and Café Tacvba, or in the electronic salsa/merengue/son covers of Kraftwerk, Yellow Magic Orchestra, Los Samplers, and Daft Punk that Señor Coconut and His Orchestra present. Music is a time machine-for my fellow Whovians, I often say that music is my TARDIS. It can help make sense of our local realities, while also rooting us in a place that is mobile. And it does this by asking us to listen.

Slavoj Žižek has commented that the enemy is "someone whose story you have not heard" (82). To know that story, to recognize the Other not as an enemy but perhaps as a potential ally, opens a space for dialogue and, hopefully, collaboration and coexistence. We need to listen to the stories that surround us so that we can create effective responses to other stories that would attempt to silence or marginalize us. Mine is a community united by stories, threaded across distance, held together by history, and bound in a book that travels with me. Part of my job, I always tell my classes-probably the smallest part-is to tell a story; the other half is to listen to others tell me theirs. In this way, hopefully, we can bridge those things that would attempt to separate us. 


\section{8 "Clumsy Sky"-Girl in a Coma}

About fifteen years after Pretty Vacant, Mendiola directed the video "Clumsy Sky" by Girl in a Coma. Three chicas chicanas from San Antonio, Girl in a Coma take their name from a song by the Smiths, but play in a style that is more influenced by punk and North American roots rock. In a way, they continue the blending of musical and cultural styles evinced in Pretty Vacant.

In their video for "Clumsy Sky," Girl in a Coma play in a Chicano bar. The bartender is an old vato veterano and the locals are older Chicanos and Mexicanos. The walls of the bar have photos of the different bands that have played in the space, primarily older Tejano bands with traditional instruments-accordion, guitar, bass. The band, three young women, play before a traditional Chicano mural of an Aztec warrior carrying an Aztec princess. "Clumsy Sky" starts slowly then quickly revs up to a hard, rocking song. As the bar begins to fill with young Chicanos and Chicanas, we see how the older bar denizens start to make connections with the newcomers. Tattoos are discussed, drinks are shared. The song ends with the photo of the band being taped to the wall, their own place assured as members of the musical community, but also the Chicano Tejano community of the bar.

\section{Bonus Track: "Somos Sur"-Ana Tijoux (Featuring Shadia Mansour)}

December, 2017. One of the classes that I taught this past semester was Chicano/a Pop Culture. I often start each class meeting with a music video which we then discuss. We work from the premise that popular culture as a site of representation can also be a site of resistance where an oppositional consciousness can be pulled out. Some of the videos include "Clumsy Sky" (Girl in a Coma), "Ingrata" (both the version by Café Tacvba and the cover by La Santa Cecilia), “There's a Light That Never Goes Out” (the Smiths song covered by the Mariachi Manchester), and "La Bamba Rebelde" (Las Cafeteras). I also invite my students to contribute with suggestions. One day, we watch Miguel's video for "Now," filmed at the High Desert Detention Center in Adelanto, California, and we talk about human rights and social justice. Another day, one student suggests "Somos Sur" by Chilean singer Ana Tijoux. The song is a collaboration with the Palestinian rapper Shadia Mansour, and is a shout-out to the global South. We talk about transnational connections, especially between the so-called Third World, and we talk about migration through the Middle World. We talk about the possibilities contained in songs, about the stories, about how they can affect us as listeners.

What does music do? It can help us imagine something better. Some may argue that poetry or music may not have an immediate political or even social effect-love will sometimes keep us together, and it will often tear us apart-but this, I argue, is 
the wrong way to approach artistic forms. There might not be an immediate effect, but there is immediate affect. Music connects and binds us in ways that may surprise us. We may discover that while this ain’t no party, this ain’t no disco, this ain't no messing around, at the same time, this just might be the place.

As my playlist comes to a close on this evening in December, 2017, I think about the transnational flows of the music of my life, of the stories that can be shared, of the connections that can be made in the crossing of borders. If there is one constant in my life, it is crossing borders. If my work has any meaning, it's because I live/travel across borders with neither fear nor with a fixed route-wandering is my friend. It's because I often carry a better soundtrack-in my head. It's because the people I meet always have interesting stories to tell. While others fear border crossing because of the supposed danger, I prefer it for the cultures and dialogues that arise in the meeting of communities: Yes, I am an unrepentant border crosser. ${ }^{138}$

\section{Works Cited}

Breytenbach, Breyten. "Notes from the Middle World.” Notes from The Middle World. Haymarket, 2009, pp. 135-156.

Chambers, lain. Migrancy, Culture, Identity. Routledge, 1994.

Crosthwaite, Luis Humberto. Out of Their Minds: The Incredible and (Sometimes) Sad Story of Ramón and Cornelio. Translated by Johnny Byrd, Cinco Puntos P, 2013.

Eco, Umberto. Interview by Susanne Beyer and Lothar Gorris. Der Spiegel, 11 Nov. 2009, www. spiegel.de/international/zeitgeist/spiegel-interview-with-umberto-eco-we-like-lists-becausewe-don-t-want-to-die-a-659577.html. Accessed 10 Dec. 2017.

Fuguet, Alberto. The Movies of My Life. Translated by Ezra E. Fitz, Rayo, 2003.

Gáspar de Alba, Alicia. Chicano Art Inside/Outside the Master's House: Cultural Politics and the CARA Exhibition. U of Texas P, 1998.

Gonzalez, Martha. "Caminos y Canciones en Los Angeles, Ca." The Tide Was Always High. The Music of Latin America in Los Angeles, edited by Josh Kun, U of California P, 2017, pp. 267-275.

Girl in a Coma. “Clumsy Sky.” Directed by Jim Mendiola, Blackheart Records, 2007.

Habell-Pallán, Michelle. Loca-Motion. The Travels of Chicana and Latina Popular Culture. New York UP, 2005.

Hornby, Nick. High Fidelity. Riverhead, 1995.

Lipsitz, George. "Cruising Around the Historical Bloc: Postmodernism and Popular Music in East Los Angeles.” Cultural Critique, vol. 5, 1986-1987, pp. 157-177.

---. Dangerous Crossroads: Popular Music, Postmodernism, and the Poetics of Place. Verso, 1994. Kun, Josh. Audiotopia. Music, Race, and America. U of California P, 2005.

Kun, Josh, editor. The Tide Was Always High. The Music of Latin America in Los Angeles. U of California P, 2017.

Pretty Vacant. Directed by Jim Mendiola, Mero Mero Pictures, 1995.

138 If you are interested in this playlist, I've made it available on Spotify. The title is "songbook": open.spotify.com/user/santv66/playlist/0NTSD02U64b9Q7eSmZTC9a 
Saldívar, José David. Trans-Americanity. Subaltern Modernities, Global Coloniality, and the Cultures of Greater Mexico. Duke UP, 2012.

Sánchez, Ricardo. "It is urgent." Canto y grito mi liberación. The Liberation of a Chicano Mind, Anchor Books, 1973, p. 131.

Ybarra-Frausto, Tomás. "Raquachismo: A Chicano Sensibility." Chicano Aesthetics: Rasquachismo. MARS, 1989, pp. 5-8.

Žižek, Slavoj. Violence: Six Sideways Reflections. Picador, 2008. 